\title{
IS UNIVERSALISM AN IMPLICATION OF THE NOTION OF POST-MORTEM EVANGELISM?
}

\author{
R.R. Cook
}

\section{Summary}

As an exercise in philosophical theology rather than biblical exegesis this article probes the rational consistency of the position held by $C$. Pinnock that both accepts the idea of a post-mortem evangelism which would provide maximum opportunity for each person to turn to God and thus find complete fulfilment and happiness, and yet also contends that nevertheless not everyone will choose to be saved. Through an analysis of why people reject Christ in this life it is concluded that Pinnock is in fact consistent although his arguments need strengthening.

\section{Introduction}

In his recent book, $A$ Wideness in God's Mercy, C. Pinnock reiterates his long-held belief in the doctrine of post-mortem evangelism, that is the view that the offer of salvation will be extended beyond the grave, but he emphatically refuses to countenance the doctrine of universal salvation on the ground that it must entail divine determinism. ${ }^{1}$ Certainly it can be argued that guaranteeing universal compliance to gospel demands would require the transformation of autonomous subjects into manipulated objects. Ironically the resultant creature would not be valuable enough to be worth saving. To quote J. Hick, 'In forcing man into his kingdom God would have turned the human thou into an it. ${ }^{2}$ As a convinced Arminian keen to preserve human freedom Pinnock therefore concludes, 'God does not purpose to condemn anyone, but

${ }^{1}$ C.H. Pinnock, $A$ Wideness in God's Mercy (Grand Rapids: Zondervan, 1992).

2J. Hick, Death and Eternal Life (London: Macmillan, 1976) 243. 
anyone can choose rejection. ${ }^{3}$ The purpose of this paper is not to provide a detailed examination of the biblical case either for the possibility of repentance after death or for universalism. I will leave the careful exegesis of intriguing verses like 1 Peter 4:6 ('The gospel was preached even to the dead, that. . .they might live in the spirit like God') and Romans 11:32 ('For God has consigned all men to disobedience, that he may have mercy on all') to other scholars. My task is rather to probe the internal consistency of Pinnock's position in embracing the former while rejecting the latter.

\section{The Implications of Post-mortem Evangelism}

The wider context of Pinnock's argument is that God loves each of his creatures infinitely so that his wrath should not be interpreted as the rejection arising from his anger but as the frustration of a spurned lover. God's anger 'strives to conquer what stands in opposition to it. God's wrath is the wrath of love.' ${ }^{4}$ As such it will travail with the obdurate creature beyond the grave if necessary. God will pursue the lost sheep to the uttermost (Lk. 15:1-7) and the gates of the New Jerusalem will never be shut (Rev. 21:25).

Pinnock also stresses the vital insight that heaven is an intrinsic reward for responding to God in love and trust. What he is saying is that the heavenly existence is more like marriage where the reward for self-giving commitment is the marriage relationship itself rather than an extrinsic reward analogous, say, to receiving a gold watch for a life time's service to a company. In other words, Christianity is not all about living an abstemious life down here so that one can receive the keys to an impressive mansion way up yonder. As A. Farrer has put it, 'Heaven is not a cash payment for walking with God, it's where the road goes. ${ }^{5}$ Heaven should be seen not as the Muslim paradise where a life of submission to Allah is rewarded by the service of dusky maidens offering sensuous pleasures, but as

${ }^{3}$ Ibid., 156.

4 Ibid., 180.

${ }^{5}$ A. Farrer, Saving Belief (London: Hodder \& Stoughton, 1964) 140. 
the fundamental fulfilment and flourishing of one's humanity in communion with God. The noble human quest for beauty, goodness and truth finds its terminus in an intimate relationship with a Creator who is the source of these fundamental values.

Now the question for Pinnock to answer is, given the maximum opportunity for turning to God that post-mortem evangelism would offer, and given the self-evident autodestructive folly of rejecting a salvation that leads to fullness of life and joy for evermore, why conceivably would any sensible creature choose hell? Pace Pinnock, does not the notion of postmortem evangelism strongly suggest that hell will be empty? Is not universalism an inevitable implication of the notion of afterlife evangelism?

Hick thinks so for one. He is convinced that our fundamental nature is neither neutral towards God, like a stone, nor antipathetic towards him, like a demon, but the imago dei ensures, as Augustine perceived, that since we are made $a d t e$, we remain restless until we find our rest in him. Hick is postulating that the nature of our ontological structure entails that our telos is inevitably godward; there is a sort of gravitational pull towards the divine. He admits that people harbour religious inhibitions of various kinds and degrees so that God needs to be pictured as an infinitely wise psychiatrist who works tirelessly to free his patients from inner blocks so as to liberate them into the realisation of their full humanity. Beyond this life, according to Hick, God can offer fresh challenges and manipulate the environment to this end. He can even jolt the patient by the equivalent of therapeutic electric shock treatment in a way rarely experienced in this life. Hick concludes,

We have to suppose, not a human but a divine therapist, working not to a limited deadline but in unlimited time, with perfect knowledge, and ultimately controlling instead of being restricted by the environmental factors. In so far as we can 
conceive of this, do we not find that it authorises an unambiguously good prognosis?

J. Robinson offers a not dissimilar picture. He too is keen to preserve human freedom while postulating universalism. The image of the divine lover attracts him and he feels that the inevitable final capitulation is rather like having one's resistance 'melted' in the face of intense human love so that one's freely given loving response becomes a means of personal liberation rather than a threat to freedom. ${ }^{7}$

It is rather beginning to look as if Pinnock's major objection to universalism is proving baseless. If Hick and Robinson are correct, universalism does not entail determinism. Will the penny soon drop, then, so that those evangelicals who choose to follow Pinnock and others of the calibre of Brunner and Pannenberg in espousing a doctrine of future probation recognise the logic of their position and eventually come out of the closet and admit that universalism seems likely since free beings would probably choose salvation given post-mortem opportunity? Can we predict that just as the once unmentionable doctrine of conditional immortality suddenly found itself on the evangelical agenda, so in a few decades' time universalism will be recognised as an evangelical option? Most evangelicals would view this as a nightmare scenario.

And yet how can the Arminian with his concern for human autonomy and universal divine love refuse the notion of post-mortem evangelism which seems to lead down the slippery slope to universalism? After all, Jesus clearly taught that everyone will experience a post-mortem encounter with himself as he calls the dead from their graves (Jn. 5:25) and surely, it will be argued, a God of infinite love will not deprive anyone of prevenient grace during this momentous encounter. The objection might be made that God judges the non-Christian according to the light she has received and therefore no further existential challenge beyond the grave is necessary for God to be able to judge righteously, but what about the test case of children who die in infancy? Certainly they are not developed

${ }^{6}$ Death and Eternal Life, 254.

7J.A.T. Robinson, In the End God (London: Collins, 1950) 110. 
enough when they die to possess such a heart attitude. And this is not a minor theological problem for it is estimated that approximately half of the human race has died before being able to distinguish the right hand from the left. Not only does a post-mortem decision seem called for but some sort of Hickian ongoing development since the notion of achieving sudden maturity at the threshold of death seems to threaten any sensible notion of identity continuity and development. Thus the conviction of J. Oliver Buswell must surely be rejected when he writes, 'the Holy Spirit of God prior to the moment of death, does so enlarge the intelligence of one who dies in infancy...that they are capable of accepting Jesus Christ. ${ }^{\prime 8}$ Calvinists, of course, can bypass the necessity for a decisionmaking capability by invoking the doctrine of unconditional predestination and thus consistently offer the following simple solution, 'elect infants, dying in infancy, are regenerated and saved by Christ' (Westminster Confession, 10.3) but it must be supposed that there still remains for them the problem of postmortem development as saved infants grow up into maturity. Yet for theologians like Pinnock who insist that salvation is dependent on a free-will response to God the necessity for a belief in post-mortem evangelism, for dead babies at least, seems inescapable unless the doctrine of the infinite love of God is compromised either by conceding that he only loves and reveals himself to some (predestinationism revisited) or that he loves all but only to a limited degree so that no one is pursued beyond the grave.

Perhaps one strategy remains for the Arminian who wants to deny future probation because of its apparent universalist implications, and that is to contend that the soul outlives the body but in an unconscious state such that decision making is rendered impossible. R. Swinburne would seem to hold this 'soul-sleep' view when he likens the relationship between the brain and the mind to that of an electrical socket and a bulb; 9 the bulb can exist without the socket but to glow it must be plugged in. However, the doctrine of the resurrection

${ }^{8}$ Quoted in J. Sanders, No Other Name (Grand Rapids: Eerdmans, 1992) 298.

${ }^{9}$ R. Swinburne, The Evolution of the Soul (Oxford: Clarendon, 1986) 310. 
of the body entails that the bulb will ultimately find another electrical source; the soul will become conscious again. Now it would seem that the same issue of the infinite love of God pursuing the sinner to the end re-emerges at this point. Even accepting this view of the unconscious intermediate state, the sort of theology espoused by Pinnock would seem to require an eschatological evangelism post-resurrection.

\section{Objections to Universalism}

To return, then, to the question of the conceptual relationship between post-mortem evangelism and universalism. Is it legitimate for Pinnock to separate the two? Let us take a closer look at his reasons for rejecting the latter. He sees universalism as extolling the infinite patience of God so that 'After a thousand invitations the hardest sinner supposedly becomes tired of saying no.' 10 But he has two problems with this. Firstly, there are too many biblical texts warning of hell which suggest that rejection is possible. These cannot be idle threats but must present a genuine danger to be avoided. Secondly, a free creature cannot be compelled. God's love cannot be irresistible unless the human will is divinely determined.

Now accepting something like Pinnock's final point, some like F. Schleiermacher have taught universalism within a determinist framework, while others like N. Ferré have attempted to hold together both universalism and human freedom while admitting that they are logically incompatible (God's ways must transcend human logic). 11 But for those who feel that the acceptance of a logical nonsense into their theological system exacts too high a price, Pinnock's objection may seem cogent enough. S. Travis, for one, agrees when he

${ }^{10}$ C.H. Pinnock, A Wideness in God's Mercy, 156.

${ }^{11}$ F. Schleiermacher, The Christian Faith (ed. H.R. Mackintosh \& J.S. Stewart; New York: Harper \& Row, 1963) 2: 539-60, 720-22; N. Ferré, The Christian Understanding of God (London: Greenwood Press, 1979). For a brief account of the position of these two theologians see, D.J. Powys, "The Nineteenth and Twentieth Century Debates about Hell and Universalism' in N.M. de S. Cameron (ed.), Universalism and the Doctrine of Hell (Carlisle: Paternoster, 1992) 93-138. 
writes, 'Because love by definition must allow its object freedom to choose whether to respond or not, we cannot say that God's love will be successful in winning all men.' 12 But, one might reply, supposing that it is not we who are predicting that all will be saved but rather that it is God who has revealed that all will respond? And supposing that such prophecy is not an expression of omnipotence and fore-ordination (what must happen of divine necessity) but of omniscience and foreknowledge (what as a matter of contingent fact will happen), then human freedom is preserved.

Pinnock must also realise that the possibility of rejection and the genuineness of infernal threats are indeed compatible with the whole human race accepting salvation as a matter of contingent fact, partly due, perhaps to those very threats being such effective warnings (partly also, one might add, to the sort of factors outlined by Hick and Robinson as already described above). These factors suggest that Pinnock's depiction of the sinner as just worn down by tirelessly repeated offers is somewhat simplistic.

But Pinnock's first point was that Scripture does not predict a universalist eschatology; it talks about sheep and goats, about gulfs fixed, about gnashing of teeth. Hick and Robinson respond by pointing out that this is indeed one strand of the biblical material but there are also such intimations of universalism as Romans 5:12-21 and Revelation $5: 13$. They would say that the latter passages express matters 'from above', that is from God's knowledge of the eschaton, and the former 'from below', that is from man's perspective of facing a genuine and infinitely important existential choice whereby it is recognised that if one were decisively to reject God then Hell would become one's sure destination. The warnings must be preached because heaven is always a state of 'having chosen'. K. Ward agrees: 'Talk of Hell is not meant to be a prediction of what will happen to most people. It is a

12S. Travis, I Believe in the Second Coming (London: Hodder \& Stoughton, 1982) 203. 
reminder of the ultimately destructive consequences of our failure to love.' 13

Some evangelicals wield Scripture in a slightly different way in an attempt to demolish the universalist case. It is argued that a whole range of doctrines are placed in jeopardy, from the necessity of saving faith to the importance of the atonement. $E$. Blum concludes, 'Universalism trivialises sin by effectively denying that sin deserves punishment.' 14 This of course is wholly unfair. While nineteenth-century liberal universalism may have trivialised sin, the kind of universalism that, say, Barth hoped for took sin very seriously but taught that the massive achievement of Christ's atonement would prove to be more than a match for it. Universalism is perfectly compatible with other central doctrines including atonement, sin, and the necessity of repentance and faith. Furthermore, the evangelism imperative remains in place given that eternal life begins at conversion, it being God's will that people enjoy a fulfilling life of service in this life as well as the next. Indeed, it can be cogently argued that once post-mortem evangelism has been embraced, nothing further is conceded theologically by accepting universalism.

But what of another important doctrine: the Fall? If Hick is right about man's godward orientation why did the Fall ever happen? Well, this is a non-problem for Hick himself since he rejects this doctrine in favour of an Irenaean theodicy but those committed to an Augustinian theodicy might argue that the parable of the Prodigal Son provides a clue. As J.N. Darby is reported to have said, 'When we are hungry we are satisfied with the husks, but when we are famished we seek the Father.' It is through trial and error that the human race finds its true home and fulfilment. The immediate pleasure looks so enticing and must often be tried but perhaps it will be finally discovered to be deeply unsatisfying. Recalling his mis-spent past, Augustine once said that dream fruit tastes like real fruit but it does not sustain.

${ }^{13} \mathrm{~K}$. Ward, The Rule of Love (London: Darton, Longman \& Todd [Daybreak], 1989) 19.

14E.A. Blum, 'Shall You Not Surely Die?' in Themelios 4 (January 1979) 61. 
But to return to the original question of why anyone would knowingly reject the post-mortem offer of eternal happiness, another reply might be that there is no rationally satisfying reason, for part of the mystery of evil is that it is irrational; it is the surd of the universe. J. Sanders, for example, states that 'Sin does not make sense, even to God (Je. 3:7).'15 This may indeed be so but the philosopher will want to probe a little deeper.

\section{The Gospel and the Human Will}

Let us begin by asking why people choose to reject the gospel in this life. First there is the important factor of the unconvinced intellect. People are simply not persuaded that what Christianity teaches is factually correct. Presumably an afterdeath encounter with the living Jesus will rectify that!

Secondly there is what may be called the weak will. Swinburne helpfully explains that the opposite of a good will is not an evil will but a weak will which succumbs to pressing and immediate desires rather than to what it knows ought to be chosen. ${ }^{16}$ Effort and struggle are required to counteract the strongest desire and if the agent relaxes and does nothing, inevitably the most powerful desire will win. The long term good is forfeited for short term pleasure. 'Make me holy but not yet.' Just as the smoker will not forfeit his pleasure in order to ward off lung cancer so the con-artist will not repent of his enjoyable trade so as to avoid hell. Sin is not senseless or pointless. To indulge the immediate desire is not totally irrational; it is done for a reason and that reason is instant gratification.

Then thirdly, there is the deadly danger that the weak will becomes the impotent will. C.S. Lewis speaks of the hopeless soul which consists 'of a will utterly centred in its self and passions utterly uncontrolled by the will... a loose

15J. Sanders, No Other Name, 113.

16R. Swinburne, Responsibility and Atonement (Oxford: Clarendon, 1989) 45. 
congeries of mutually antagonistic sins rather than a sinner' ${ }^{\prime}{ }^{17}$ Swinburne explains how a process of self-deception can develop in the one who habitually refuses the good whereby he either persuades himself that his bad choices are actually good (e.g., 'the rape victim enjoys it really'), or that morality as such should be disregarded. The end of this process is soul-suicide where the ability to discern and choose has been completely destroyed. The individual becomes merely 'an arena of competing desires'18 where the strongest desire always wins. To borrow Freudian terminology it could be said that the superego has been destroyed so that one becomes a true id-iot. In 1 Timothy 4:2 we read of 'hypocritical liars, whose consciences have been seared as with a hot iron'. As an aside it should be noted at this point that only a few (e.g., sociopaths) reach this lamentable condition this side of the grave so that if hell is full of such, then further degeneration must be possible after death. To return to Swinburne, 'an agent who has over time deliberately suppressed his awareness of the good in all areas will have built up a strong desire, which belongs to the central structure of his soul, to resist all such awareness.'19

This is a timely reminder that we do not enter the afterlife as a tabula rasa. As Heidegger remarked, we are born as anyone and die as someone. There is a wise old proverb which runs, 'sow an action, reap a habit; sow a habit, reap a character.' We are largely what we have chosen to become and choices have serious consequences. It is this conviction that compels $\mathrm{G}$. Jantzen to cross swords with Hick. I quote her at length:

If I perpetually choose selfishness and distrust and dishonesty, and my character is formed by these choices, it seems perverse to say that eventually these choices will be reversed and I will attain the same moral perfection as I would have if I had all along chosen integrity and compassion. Part of what it means to be free is that our choices have consequences; it is playing much too lightly with

${ }^{17}$ C.S. Lewis, The Problem of Pain (London: Collins [Fontana], 1957; first published 1940) 114.

${ }_{18}$ R. Swinburne, Responsibility and Atonement, 175.

19Ibid., 178. 
the responsibility of freedom to suggest that these consequences, at least in their effects upon ourselves, are always reversible, even if only in the endless life to come. ${ }^{20}$

Now, perhaps she overstates her case. The same eternal life is promised even to those whose repentance comes late in their human career, as parables such as that recorded in Matthew 20:1-16 demonstrate. But certainly a change of heart does become progressively more difficult. It is a matter of record that few middle aged and older people undergo religious conversions. Travis also feels that Hick's picture of the divine psychiatrist with a hundred percent success rate is weak at this point:

Is it not psychologically and spiritually true that persistent refusal to respond to love makes response harder rather than easier? The more often we are moved to do something and fail to do it, the less likely it is that we will ever do it.21

It can be argued that, depending on who we have made ourselves or who we have allowed ourselves to become, the same divine love will be perceived as either intolerably demanding and disruptive or wonderfully liberating. In the words of the proverb, 'the same sun that hardens the clay, softens the wax.' Because of the hardness of their hearts, some of the Pharisees interpreted Jesus' divine acts as demonic and it is this sort of perversity that Jesus had in mind when he warned against the unpardonable sin against the Holy Spirit. God comes to offer himself, the source of beauty, goodness and truth, but because of their evolved twisted character, some may only perceive a being who personifies ugliness, evil and lies. 'To the pure, all things are pure, but to those who are corrupted and do not believe, nothing is pure' (Tit. 1:15). Did not Nietzsche find the gospel of humble, self-giving love despicably weak and repulsive? This may be called, fourthly, the perverse will. It should also be noted at this point that God is not simply the personification of the basic values of goodness, beauty and truth, he is not only generic $E l$, but also a specific person, Yahweh, with individual plans and preferences. As with

20G. Jantzen, 'Do we Need Immortality?', Modern Theology 1 (1984) 40.

${ }^{21}$ S. Travis, Christian Hope and the Future of Man (Leicester: IVP, 1980) 130. 
any specific and unique person, there may always be those who just do not like his company for idiosyncratic reasons of personality aversion.

Post-mortem evangelism may not only be confronted by the weak will and the impotent will and the perverse will but also by, fifthly, the proud cantankerous will. If anyone experienced emotional electric-shock treatment through painful circumstances it was benighted Othello, and having murdered his innocent wife, he is certainly a sadder and wiser man by the end of the play. Yet T.S. Eliot discerns a note of self-justification and even self-congratulation in Othello's final soliloquy which leads to the following interesting observation about human nature: 'Humility is the most difficult of all virtues to achieve; nothing dies harder than the desire to think well of oneself.'22 But humility is the sine qua non of salvation. Conversion requires both the humility of admitting that my whole life has been based on false foundations such that I have become my own catastrophe, and also that I humbly submit to the Lordship of God. Some might rather perish than admit to either. Milton's Satan is presented thus. In the following lines both the cantankerous will and the perverse will are clearly in evidence:

The mind is its own place, and in itself Can make a heav'n of hell, a hell of heav'n.

Here [in hell] at least

We shall be free; th' Almighty hath not built Here for his envy, will not drive us hence: Here we may reign secure, and in my choice To reign is worth ambition, though in hell:

Better to reign in hell than serve in heav'n. ${ }^{23}$

J. Macquarrie has shown how the inevitable finitude and contingency of creation carries with it a tragic element. While the fact that each of us constitutes a finite centre of interest and perspective does not itself entail egotism, nevertheless Macquarrie observes that this fact makes pride possible and tempting, 'for the pull or tendency that operates from the

22T.S. Eliot, Selected Essays (3rd ed; London: Faber, 1951) 130.

23J. Milton, Paradise Lost , Book 1, 1.254-263. 
beginning is to set up each one's centre as the centre of everything, and so to fall into self-idolatry',24 a state that he calls 'anthropolatry'.

These different types of perversity of will towards the divine may be helpfully brought together in an allegory. Let us take our cue from Robinson's romantic lover mentioned above while exploring the possibility of a more tragic outcome. Picture a Hosea/Gomer type of situation where the husband attempts to woo back an adulterous, promiscuous wife. Although he is a loving, gentle, morally upright, and forgiving man there is absolutely no guarantee that he will succeed. She may no longer be intellectually persuaded that monogamy is a moral virtue and so possesses an unconvinced intellect. Or she may be suffering from a weak will whereby she habitually chooses to succumb to the seductive charms of the next handsome suitor while ignoring the promptings of conscience. Or she may have convinced herself that marriage vows along with other ethical norms are inane so that no struggle with conscience remains. She has become amoral and degenerated into an impotent will. She never acts, only reacts in a Pavlovian fashion to the dictates of her libido. Or again, her perverse will may interpret her husband's kindness as weakness and his loving offer to accept her back as mere wimpishness. The more tenderness he demonstrates, the more unattractive she finds him, especially after her brutally attractive macho lovers. Or finally, perhaps her proud, cantankerous will refuses to admit that she has been wrong and refuses to seek forgiveness from her husband. She also refuses to accept the loss of autonomy that would be a result of committing herself again to the marriage vows. She insists on being mistress of her own life.

\section{Time and Choice}

Two outstanding issues need to be discussed before concluding this paper. Firstly the length of the post-mortem probationary period. So far it has been assumed that if there is to be

24J. Macquarrie, Principles of Christian Theology (rev. ed; London: SCM, 1977) 264. 
evangelism beyond the grave, then, since God's love for each individual is infinite, the offer of salvation must never be withdrawn. However, this logic is contestable. Existentialists like Camus and Sartre, (not to mention Heidegger with his interest in Sein-zum-Tode) have noted that the prospect of death positively provides a bracing awareness of one's finitude and gives urgency to one's life-shaping decisions. Similarly it could be argued that, say, the weak-willed soul would be tempted to procrastinate forever unless God made clear that the offer of salvation is not open ended. That is, there will come a time when hell will be locked from the outside as well as from the inside; it will become a genuine prison rather than just a barricaded sit-in. To borrow Hick's metaphor, such a divine warning might provide just the electric shock treatment required to jolt many into making a decision to capitulate to God's will and accept his offer of salvation. The warning that God will one day withdraw this offer could thus be perceived as a loving act.

Secondly, the wisdom of procrastinating throughout this life needs to be discussed. After all it could be argued that the rational course for one to take if opportunity for decisionmaking continues after death is to wait until that time before making a decisive choice regarding the Christian religion, for then evidence amounting to proof is promised and in the interim one can quite simply enjoy oneself. However, the fallacy with this position is that it wrongly assumes that one can happily live in a neutral state regarding the issue of God's existence from womb to tomb. Rather, this issue is like other basic ones such as the existence of other minds or the reality of free-will. They are all matters which are not susceptible to rational proof and yet issues which cannot be ignored. We all live our lives assuming either that people have minds like us or they do not, or that they are free and therefore responsible or they are not. We cannot remain agnostic. We have to orientate our lives one way or the other. Similarly, it can be argued, we all live as if there is a God or not. The God issue cannot blithely be postponed. The quest must be followed here and now. The nature of true enjoyment and fulfilment is connected with the question of human purpose which again relates directly to the 
issue of God's existence and his plans for humanity. For any responsible individual the quest for meaning and truth cannot be put in abeyance.

\section{Conclusion}

Finally, it is my conclusion that although Pinnock does not provide a very satisfactory or adequate account of his position, it transpires that he is nevertheless rationally consistent in embracing the notion of post-mortem evangelism while eschewing universalism. Universal salvation does not necessarily follow even if God proves to be as the Tekoan woman maintains when she declares, 'Like water spilled on the ground, which cannot be recovered, so we must die. But God does not take away life; instead, he devises ways so that a banished person may not remain estranged from him' (2 Sa. 14:14). Due to the weak will degenerating into the impotent will, the perverse will committing the ultimate sin against the Holy Spirit, and the cantankerous will refusing to bow the knee, some souls may remain obdurate to the end. Whether this will in fact transpire, the omniscient God only knows and we must remain totally dependent on the sound exegesis of his inscripturated revelation for our knowledge of such matters which has not been the purpose of this essay. 